\title{
An integrated framework for Web-based visualisation of forest resources estimated from remote sensing data
}

\author{
Róbert Cibula ${ }^{1}$ Ivan Sačkov ${ }^{2 *}$ \\ ${ }^{1}$ State Geological Institute of Dionýz Štúr, Department of Geological Information Systems, Mlynská Dolina 1, \\ SK-81704 Bratislava 11, Slovak Republic \\ ${ }^{2}$ National Forest Centre - Forest Research Institute Zvolen, T. G. Masaryka 2175/22, SK - 96001 Zvolen, Slovak Republic
}

\begin{abstract}
Advanced remote sensing technologies has recently become an effective tool for monitoring of forest ecosystems. However, there is a growing need for online dissemination of geospatial data from these activities. We developed and assessed a framework which integrates (1) an algorithm for estimation of forest stand variables based on remote sensing data and (2) a web-map application for 2D and 3D visualisation of geospatial data. The performance of proposed framework was assessed in a Forest Management Unit Vígl'aš (Slovakia, Central Europe) covering a total area of $12,472 \mathrm{ha}$. The mean error of remote sensing-based estimations of forest resources reached values of $16.4 \%, 12.1 \%$, $-26.8 \%$, and $-35.4 \%$ for the mean height, mean diameter, volume per hectare, and trees per hectare, respectively. The web-map application is stable and allows real-time visualization of digital terrain model, aerial imagery, thematic maps used in forestry or geology, and 968,217 single trees at forest management unit level.
\end{abstract}

Key words: geo-visualization; WebGL; level of details; Forest inventory; airborne LiDAR

Editor: Tomáš Hlásny

\section{Introduction}

The use of remote sensing (RS) data in forest inventory has increased the efficiency of managing forest resources considerably (Vauhkonen et al. 2014; Ginzler \& Waser 2017). In recent years, data from both active and passive sensors have been widely applied for estimations of biophysical variables such as mean height, mean diameter, standing volume, tree species, basal area (Surový \& Kuželka 2019).

However, the application of RS data within the managing forest resources is still not utilised to its full potential. The primary reason is that most of potential stakeholders in forestry sector (foresters, forest owners, environmentalist, policy makers, etc.) often lack (1) adequate budget to ensure the specific technical and data infrastructure, (2) know-how and skills to use the specific software and data, and (3) time or motivation to learn how to use new methods and techniques.

A web-based visualization technologies present an opportunity for providing complex geospatial data and findings from RS-based estimations of forest resources in simpler manner. In this case, (1) data, users and applications work interactively in a distributed environ- ment and there is no necessity for installing a specific geospatial software, (2) users can interact with the upto-date data without relying on the platform, and (3) collaborative data analysis is possible as most of the modern web browsers support the implementation of visualizations without requiring any other software installation (Cibulka 2012; Ma et al. 2019).

The main goal of this study is to present an integrated framework for web-based visualisation of forest resources estimated from RS data in Forest Management Unit Víglaš (Slovakia, Central Europe) covering a total area of 12,472 ha. The forest stands variables, such as mean height, mean diameter, volume per hectare, and trees per hectare, were estimated through an individual tree detection algorithm implemented in the remote forest land explorer (reFLex) software based on airborne LiDAR data and aerial color-infrared images. This technology concept has previously been verified in different types of central European forests (e.g. Sačkov et al. 2016, 2017a, 2019). The web-map application was developed as a single page application primarily using Arcgis API libraries for Javascript. 


\section{Materials and methods}

\subsection{Study area, datasets and framework}

The study was conducted in the territory of the Forest Management Unit Víglaš (Fig. 1) located in central Slovakia (approx. $48^{\circ} 32^{\prime} \mathrm{N}, 19^{\circ} 21^{\prime} \mathrm{E}$ ). The total area is 12,472 ha and forests occupy 3,215 ha from this area. The elevation of the study area reaches intervals of 374 978 meters above sea level. Dominant species in the area include European beech (Fagus sylvatica L.), Sessile oak (Quercus petraea Matusch), and European hornbeam (Carpinus betulus L.) with 65\% coverage. The area of the remaining part is covered by conifers, such as European silver fir (Abies alba Mill.) and Norway spruce (Picea abies L.). with Diameter at Breast Height (DBH) higher than $7 \mathrm{~cm}$ were measured for stem position, species, height, diameter, and vitality.

The workflow of integrated framework for RSbased estimation and web-based visualization of forest resources is shown in Fig. 2 and described in detail in following sections.

\subsection{Estimation of forest resources}

The treetops, tree crowns, and tree heights were detected from airborne LiDAR data using the reFLex algorithm (National Forest Centre, Zvolen, Slovakia). These outputs were subsequently exported to point (tree tops) and

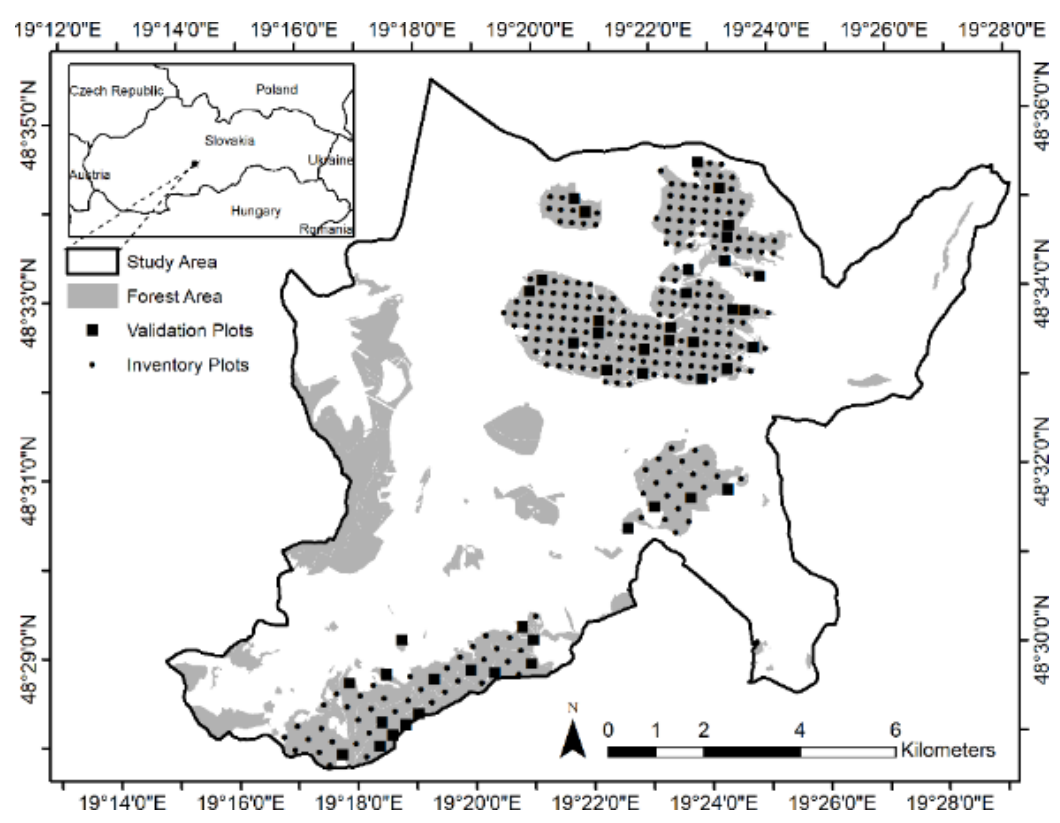

Fig. 1. Location of the study area: Forest Management Unit Víglaš.

Airborne LiDAR data acquisition was performed in September 2016 using a Leica ALS 70 CM scanner. The study area was scanned from an altitude of 1,290 $\mathrm{m}$ with a $43^{\circ}$ field of view, and $282 \mathrm{kHz}$ laser pulse repetition rate. The resulting average density of point cloud reached 26 points $\mathrm{m}^{-2}$. The airborne Lidar-derived digital terrain and surface model (DTM and DSM) were interpolated in SCOP++ Software environment (Trimble) and vertical accuracy was expected to be $\pm 0.2 \mathrm{~m}$. A canopy height model $(\mathrm{CHM})$ of $0.5 \mathrm{~m}$ resolution was generated as a result of subtraction of the DSM and DTM.

Ground reference data were obtained during the leafon season in 2017 within 294 circular plots with radius from 7.5 to $20 \mathrm{~m}$ (size of plot was dependent on number of trees). The position of the plot centre was measured using the Global Navigation Satellite System (GNSS) and a positional error from $1.44 \mathrm{~m}$ to 6.25 was expected for all plots (Murgaš et al. 2018). A total of 8,846 trees polygon (tree crowns) vector files in an ESRI shapefile format (Sačkov et al. 2017b).

Tree species of detected trees were determined at the level of identified objects and were classified only into general classes of broadleaved and coniferous trees. For this purpose, an object-oriented classification of RGB and CIR orthophotos with a spatial resolution of $0.25 \mathrm{~m}$ was used. This classification was processed with the eCognition Developer 8 software (Trimble GeoSpatial, Munich, Germany).

The DBHs of the detected trees were derived based on nonlinear regression models. The model predictor was tree height for the selected group of tree species $(\mathrm{DBH}=$ $\mathrm{f}(\mathrm{h})$ ). The calibration dataset included 955 broadleaved trees and 747 coniferous trees. The statistical significance of models was assessed using the F-test at a significance level of $\alpha=0.05$. The average accuracy for these models was $21 \%$ at the tree level. 


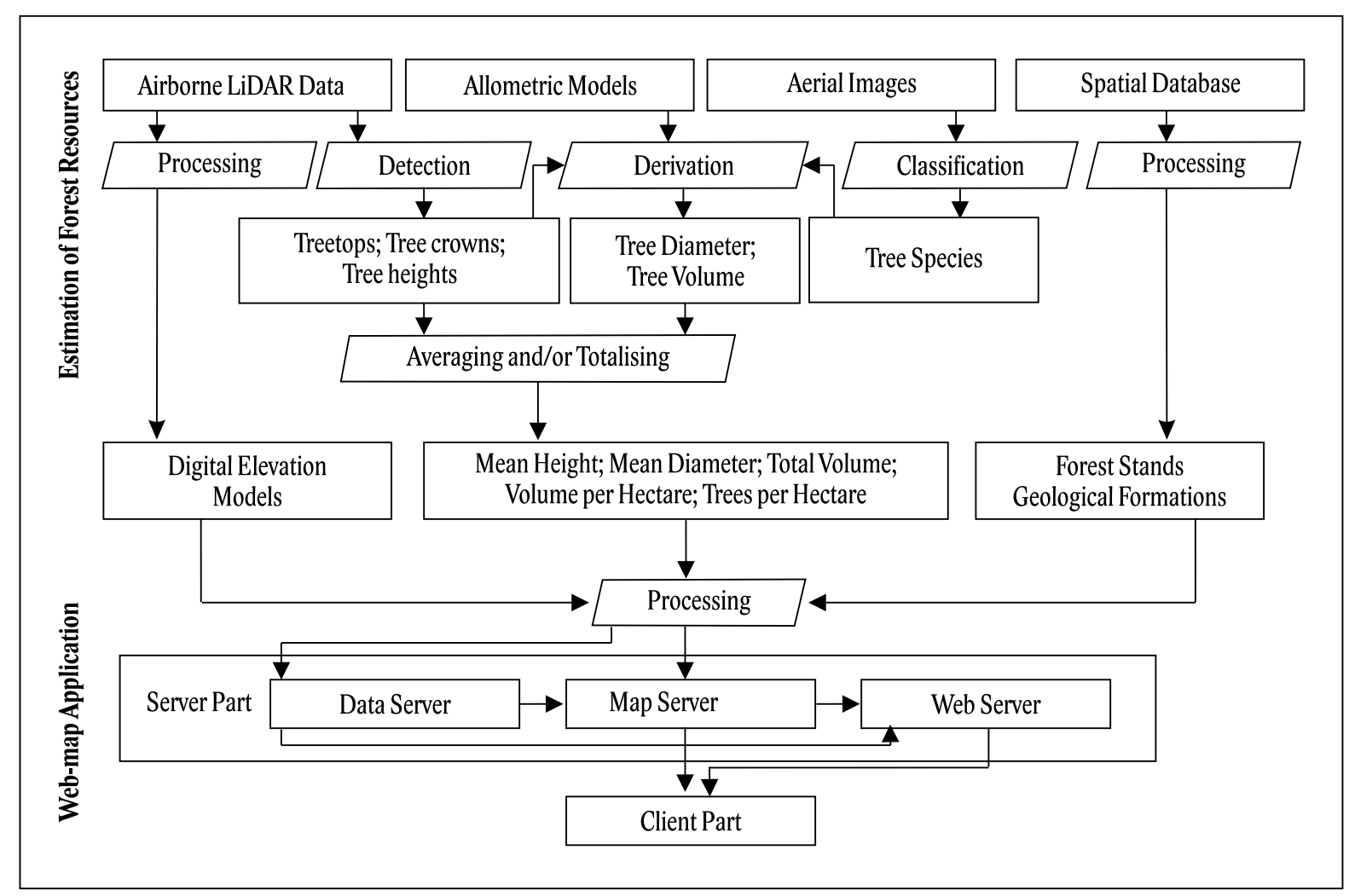

Fig. 2. Integrated framework for remote sensing-based estimation and web-based visualization of forest resources.

The volume for detected trees was derived based on the models introduced by Petráš \& Pajtik (1991). For each remotely detected tree, which included the estimated height, assigned attribute of tree species classes, and derived DBH, the volume calculation was applied using the adopted model. As only two classes of tree species were available, the volume functions of the tree species with the highest proportion in the respective growing stock were used as a compromise. For the broadleaved class, the beech function was used. For the coniferous class, the spruce function was used.

Finally, the stand height and stand diameter were calculated as the average of the tree data. The total volume was calculated as a sum of the tree volumes.

\subsection{Development of Web-map application}

\section{Data formats}

The functionality of web-map applications strongly depends on the format of datasets that are displayed to the user via a web browser. The basic requirement is to display the required amount of data in the shortest possible time and in the best possible quality.

In this context, Indexed 3D Scene Layers (i3s) and Limited Error Raster Compression (LERC) data formats were used for the current version of the application. The i3s format was used for streaming large and heterogeneous geospatial datasets with $3 \mathrm{D}$ content including discrete 3D objects, large continuous meshes, 3D vector points, and point clouds. The LERC format was used to create a custom tile layer that displays elevation data.

\section{Application}

The server part of the application consists of three interconnected servers: (1) Data server: we selected PostgreSQL object-relational database management system because this system is freely distributable and, among other benefits, it supports a large part of the SQL standard and extension, including a spatial database extender PostGIS. (2) Map server: we selected ArcGIS Enterprise 10.7.1 (ESRI) because this system provides many of the features needed for mapping, data analysis, data visualization, and recent releases include also support for publishing 3D objects. (3) Web server: we selected Apache with PHP configuration for hosting an application because this server is freely distributable and providing some built-in resources such as databases, caching tools and other tools for website optimization.

The client part of the application was created as a single page application (SPA) using Arcgis API libraries for Javascript as well as through Query, UnderscoreJS, Backbone, Bootstrap, and jsPanel. SPA interacts with the user by dynamically rewriting the current page rather than loading entire new pages from a server. This approach avoids interruption of the user experience between successive pages. For more realistic 3D visu- 
alization of RS-identified trees, we used a model from ESRI 3DVegetation Library (Peterson 2014). However, only conifer model was adopted for current version of the application. In this context, we used also the concept of "Level Of Detail" (LOD) to increase rendering efficiency by reducing (1) number of objects and (2) complexity of the $3 \mathrm{D}$ object, when the scale is changing.

\section{Results}

\subsection{Estimations of forest resources}

A total of 968,217 single trees were detected using reFLex algorithm. The RS-based approach evaluated the mean height at $22.3 \mathrm{~m}$ by averaging the detected tree heights, the mean diameter at $26.2 \mathrm{~cm}$ by averaging the derived tree diameters, the volume at $744,732.6 \mathrm{~m}^{3}$ by totaling the calculated tree volumes. The differences between ground-measured and RS-estimated forest stands variables reached values of $16.4 \%, 12.1 \%,-26.8 \%$, and $-35.4 \%$ for the mean height, mean diameter, volume per hectare, and trees per hectare, respectively. Additionally, the variability of ground-measured and RS-estimated tree height, tree diameter and tree volume is shown in Fig. 3. geology (e.g. geological formation). This panel also includes an output from the RS-based estimation of forest resources (e.g. RS-identified trees). The visualization of the RS-identified trees is changing dynamically with respect to the scale. The scales of more than $1: 20,000 \mathrm{~m}$ allows a visualization of trees only as raster object in both 2D and 3D scene (Fig. 5a). The scales from 1:20,000 to 1:1,000 m allows a visualization of tress as vector object (Fig. 5b). The scales less than $1: 1,000 \mathrm{~m}$ also allows a visualization of trees with the unified $3 \mathrm{D}$ graphics of conifers and moreover, the size of these $3 \mathrm{D}$ objects reflects to the RS-estimated tree height and crown projection (Fig. $5 c)$. The web interface of application also contains a set of geographic tools. In addition to the basic functionality (e.g. zooming, selecting, etc.), the application allows to create cross-sections through layers as well as a measurement of transversal, horizontal and direct distance between individual 3D objects (e.g. tree tops) (Fig. 6).

An initial experiments showed that the web-map application is fully stable and allows real-time visualization of geospatial data. More specifically, the average response time to display page with several hundred trees including 3D graphics of conifers (scale $<1: 1,000$ ) or several hundred thousand trees (scale $1: 1,000$ $1: 20,000$ ) was about 5.3 seconds.

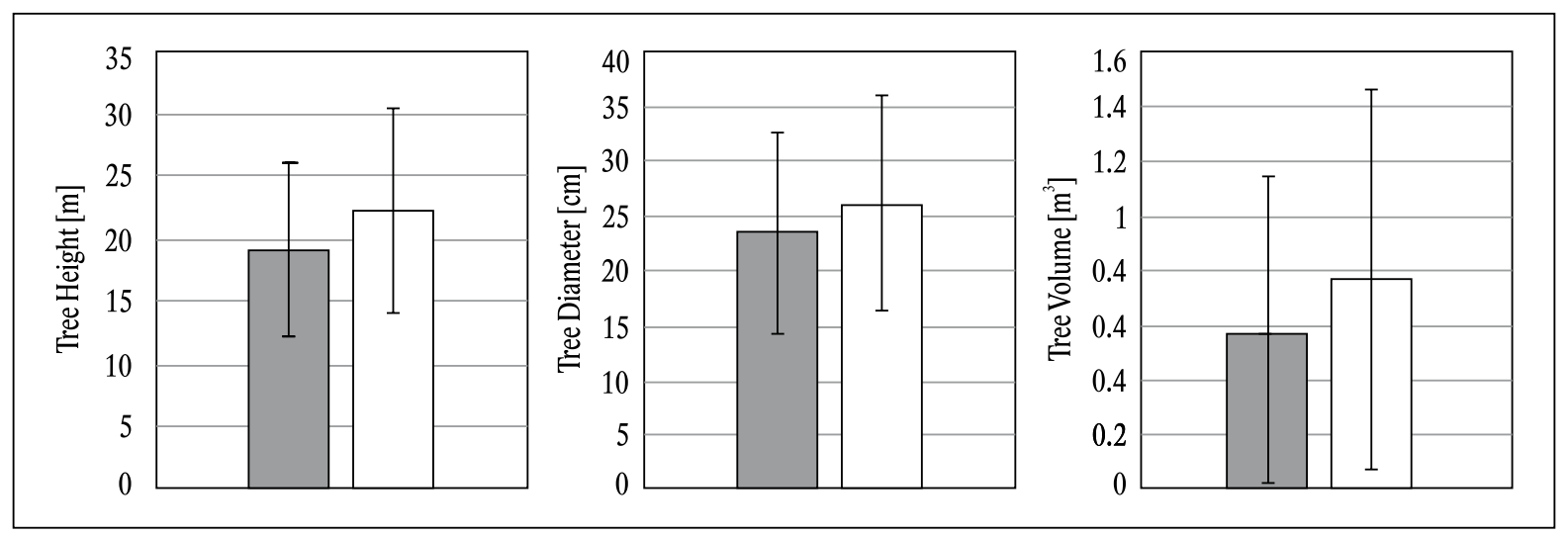

Fig. 3. Ground-measured (grey box) and remote sensing-estimated (white box) forest stand variables including standard deviation (whiskers).

\subsection{Visualization of forest resources}

The application enables the web-based visualization of geospatial data in 2D and 3D scene including attributeand location-based querying and $3 \mathrm{D}$ data profiling. The availability is provided by map servers of State Geological Institute of Dionýz Štúr and/or National Forest Centre.

The web interface of application consists of two map panels. The first panel contains background layers, such as geographic maps, orthophotos, and digital elevation models (eg. DTM). In the case of 3D visualization, the elevation layer is defined by DTM and all remaining layers are consequently rendered based on this elevation layer (Fig. 4). The second panel contains sublayers, such as thematic maps used in forestry (e.g. forest stand) and

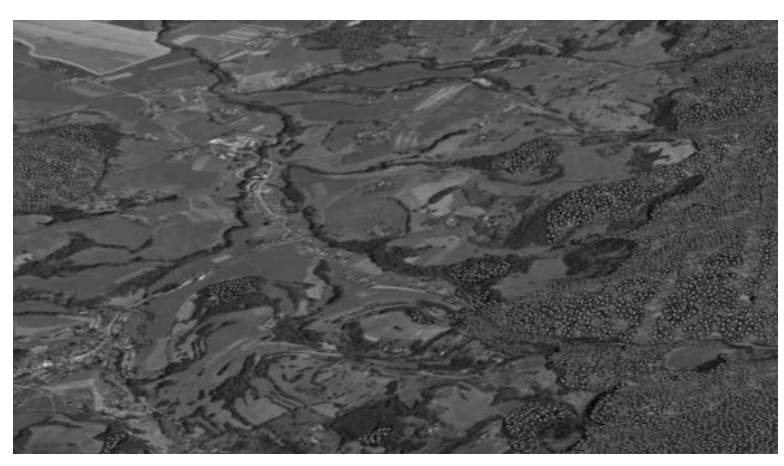

Fig. 4. Visualization of orthophotos (3D background layer) and trees (2D point sublayer). The elevation layer is defined by digital terrain model. 


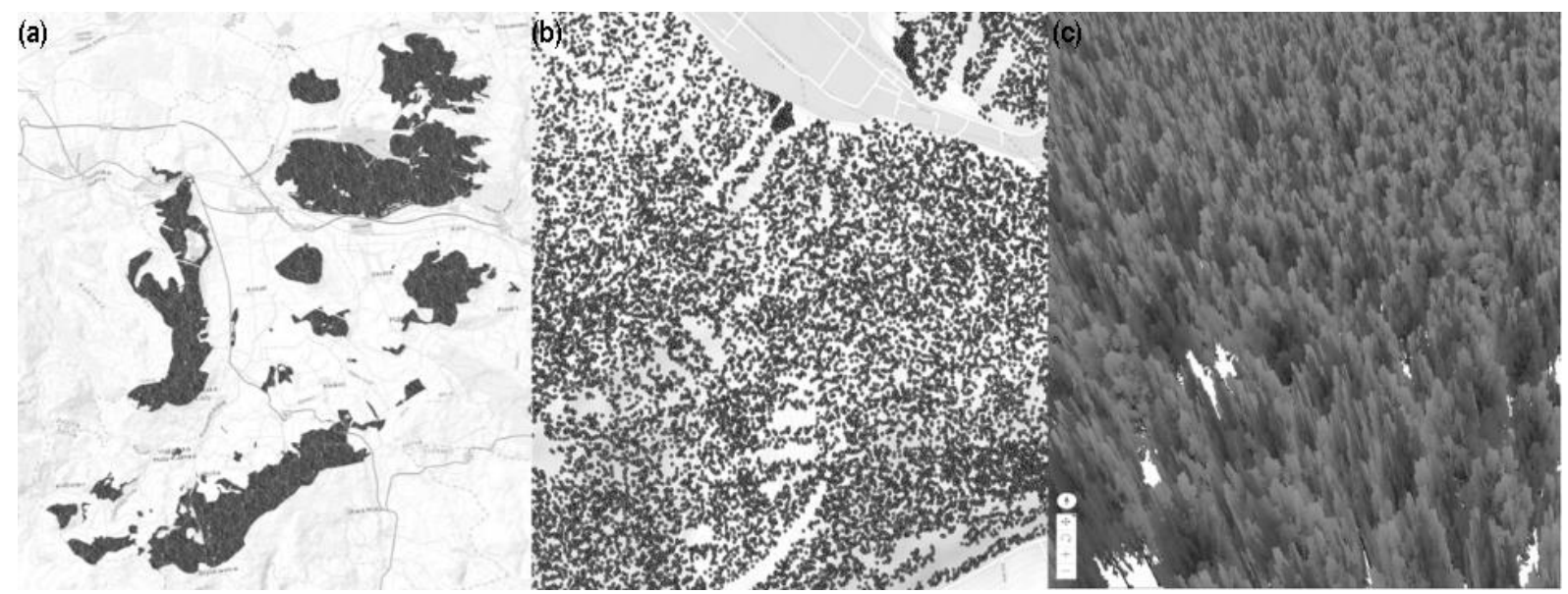

Fig. 5. Visualization of geographic map (background layer) and trees in different scales: (a) Scale $>1: 20,000$ displays trees as raster object, (b) Scale 1:20,000 - 1:1,000 displays trees as vector object, (c) Scale $<1: 1,000$ also allows a visualization of trees as $3 \mathrm{D}$ object.
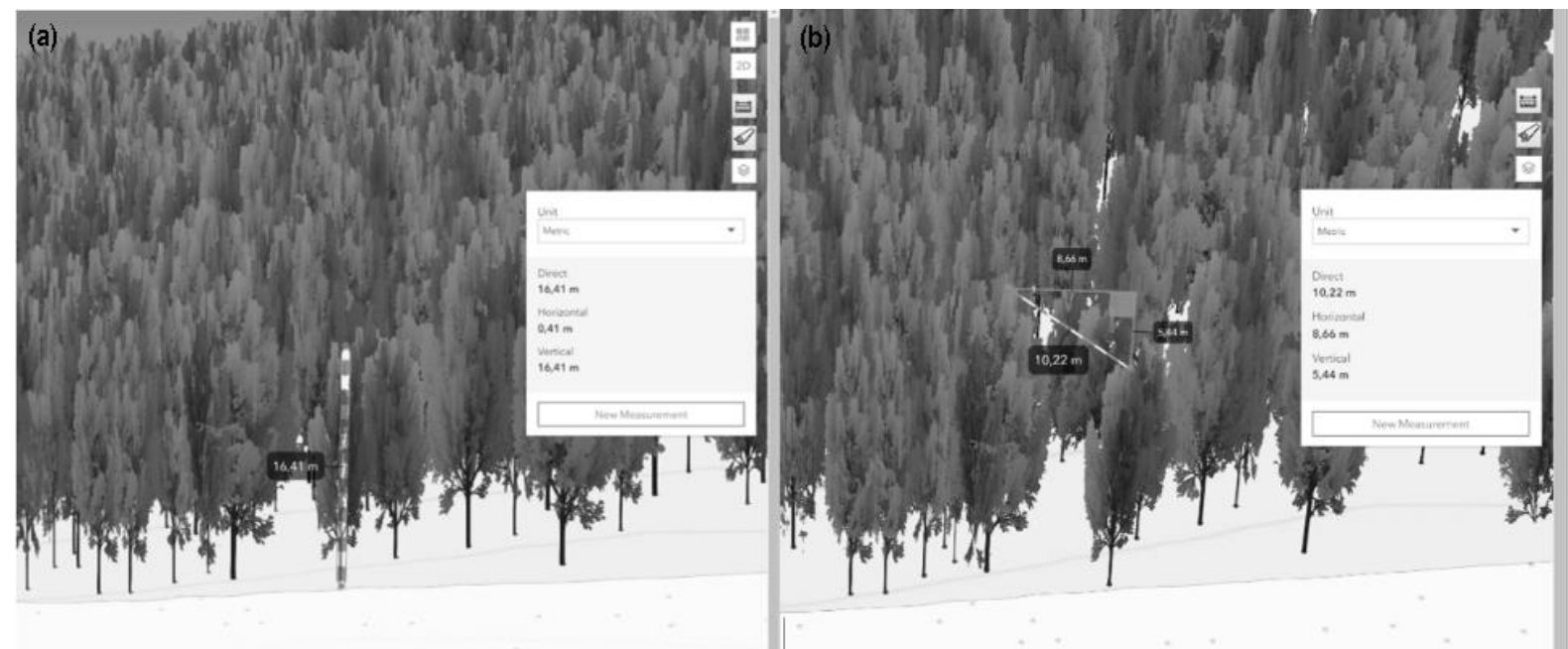

Fig. 6. The application allows to create cross-section through trees and interactive measurement of tree height (a) as well as distance between trees (b).

\section{Discussion}

A web-based visualization of forest resources estimated from RS data represents an effective technology concept to support precision forestry. Firstly, advanced RS-based techniques allow to estimate forest resources automatically, continuously, with a known accuracy, and at multiscale level. Secondly, web-map applications allow to provide geospatial data to the key stakeholders in forestry sector over mainstream web browsers. We have therefore developed a framework which integrates (1) an algorithm for estimation of forest stand variables based on remote sensing data and (2) a web-map application for 2D and $3 \mathrm{D}$ visualisation of geospatial data.

The forest stands variables were estimated through an individual tree detection algorithm implemented in the reFLex software based on combination of airborne LiDAR data and aerial color-infrared images (Sačkov et al. 2017). Although only $64.6 \%$ of single trees were identified, the mean error of RS-based estimations did not exceed $16.4 \%$ for mean height and $12.1 \%$ for mean diameter. On the other hand, the volume was underestimated by $26.8 \%$, probably due to problems in detecting suppressed and understory trees. This problem could be considerably reduced with the area-based algorithm (Kandare et al. 2017). Comparing different approaches, however, our individual tree detection algorithm provided accuracies that were higher or similar to the area-based algorithm. For example, Coomes et al. (2017), Zhang et al. (2017) or Lamb et al. (2018) reported an accuracy of $5-11 \%, 10-13 \%, 12-28 \%, 19-30 \%$ for estimation of mean height, mean diameter, standing volume, and stem density, respectively.

The developed web-map application displays the geospatial data in a user-friendly manner and it is capable of fast real-time rendering in $2 \mathrm{D}$ as well as $3 \mathrm{D}$ scene 
over mainstream web browsers without a plugin. In this context, we confirm its full applicability in design consisting (1) data formats (i3S, LERC), (2) server parts (PostgreSQL data server, ArcGIS Enterprise map server, Apache with PHP configuration web server), and (3) client part (SPA developed by Arcgis API libraries for Javascript). However, there are many other effective frameworks of web-map application that are commonly used for visualization of forest resources. Lim \& Honjo (2003) visualized a forest landscape with thousands of trees using Virtual Reality Modeling Language. Singh et al. (2012) developed a web-map application only by open source geospatial systems (e.g. Mapserver, MapScript) and observed that this application also enables user to view, update, customize, retrieve, inquire and analyse data about forest resources. Panizzoni et al. (2015) used GeoBrowser 3D, HTML5, WebGL, CSS 3D and Canvas element for interactive visualization of the forest model. Zápotocký \& Koreň (2016) proposed a web-map application for visualization of forestry maps based on Microsoft SQL Server, ArcGIS for Server, and Microsoft Information Server. Wang et al. (2017) used X3DOM and HTML5 and developed a workflow for the construction of WebGL rendering and interactive visualization of forest landscapes from GIS and forest simulation datasets. Stratil \& Renner (2019) used a Unity Gaming Technology to visualize spatial data and allowing the forest owners virtually visit their forests. Marano et al. (2019) developed a flexible web-based operational tool to challenge multifunctional and sustainable forestry knowledge for planning and management purposes at the landscape level, with a demonstration of potential deliveries at high spatial detail and for large spatial extent areas.

\section{Conclusions}

This study demonstrated that our integrated framework is capable of online providing complex geospatial data and findings from RS-based estimations of forest resources at forest management unit level. In this context, we extended the current state of art in the field of utilization of advanced geospatial technology within the forestry sector. Firstly, despite the requirement for largescale estimation of forest stand variables (12,472 ha), an accuracy of our individual tree detection algorithm was higher or similar to the other studies. Secondly, despite the requirement for online visualization of large amounts of geospatial data (e.g. digital terrain model, aerial imagery, thematic maps used in forestry or geology, and 968,217 single trees), newly developed webmap application showed stability and capability for fast real-time rendering in 2D as well as 3D scene over mainstream web browsers without a plugin.

Future work should include creation of a more detailed visualization of different surfaces (e.g., grassland, forest, open water, building) as well as trees (tree species) and development of various useful geospatial tools (e.g., interactive navigation). Furthermore, there is a potential for expanding this application which will enable the user to download, upload and analyse geospatial data for specific needs.

\section{Acknowledgments}

This research was supported by the Ministry of Agriculture and Rural Development of the Slovak Republic in the framework of the project "Research and development to support the competitiveness of Slovak forestry" (SLOV-LES).

\section{References}

Cibulka, D., 2012: Uplatnenie webových služieb pri srístupňovaní a spracovaní geodát. Ph.D. dissertation, Bratislava, Stavebná fakulta, STU v Bratislave.

Coomes, D. A., Dalponte, M., Jucker, J., Asner, G.P., Banin, L. F., Burslem, D. F. R. P.et al., 2017: Areabased vs tree-centric approaches to mapping forest carbon in Southeast Asian forests from airborne laser scanning data. Remote Sensing of Environment, 194:77-88.

Ginzler, Ch., Waser, L. T., 2017: Entwicklungen im Bereich der Fernerkundung für forstliche Anwendungen. Schweizerische Zeitschrift für Forstwesen, 168:118-126.

Kandare, K., Dalponte, M., Ørka, H. O., Frizzera, L., Næsset, E., 2017: Prediction of Species-Specific Volume Using Different Inventory Approaches by Fusing Airborne Laser Scanning and Hyperspectral Data. Remote Sensing, 9:400.

Lamb, S. M., MacLean, D.A., Hennigar, C. R., Pitt, D. G., 2018: Forecasting Forest Inventory Using Imputed Tree Lists for LiDAR Grid Cells and a Tree-List Growth Model. Forests, 9:167.

Lim, E. M., Honjo, T., 2003: Three-dimensional visualization forest of landscapes by VRML. Landscape and Urban Planning, 63:175-186.

Ma, Z., Chen, M., Zhang, B., Wang, M., Shen, C., Yue, S. et al., 2019: A web-based integrated modeling and simulation method for forest growth research. Earth and Space Science, 6:2142-2159.

Marano, G., Langella, G., Basile, A., Cona, F., Michele, C. D., Manna, P. et al., 2019: A Geospatial decision support system tool for supporting integrated forest knowledge at the landscape scale. Forests, 10:690.

Murgaš, V., Sačkov, I., Sedliak, M., Tunák, D., Chudý, F., 2018: Assessing horizontal accuracy of inventory plots in forests with different mix of tree species composition and development stage. Journal of Forest Science, 64:478-485. 
Panizzoni, G., Magliocchetti, D., Prandi, F., De Amicis, R., 2015: Interactive virtual planning tools for sustainable forest production in mountain areas. In: Stephanidis, C. (eds.): HCI International 2015 Posters' Extended Abstracts. Springer International Publishing, Cham, p. 220-225.

Peterson, B., 2014: 3D Vegetation Library Delivers Advanced Models for Urban Design and GIS Professionals. Available at https://www.esri.com/ esri-news/releases/14-1qtr/3d-vegetation-librarydelivers-advanced-models-urban-design-gis-professionals. (accessed January 30, 2020).

Petráš, R., Pajtík, J., 1991: Sústava česko-slovenských objemových tabuliek drevín. Lesnícky časopis, $37: 49-56$.

Sačkov, I., Santopuoli, G., Bucha, T., Lasserre, B., Marchetti, M., 2016: Forest Inventory Attribute Prediction Using Lightweight Aerial Scanner Data in a Selected Type of Multilayered Deciduous Forest. Forests, 7:307.

Sačkov, I., Sedliak, M., Kulla, L., Bucha, T., 2017a: Inventory of Close-to-Nature Forests Based on the Combination of Airborne LiDAR Data and Aerial Multispectral Images Using a Single-Tree Approach. Forests, 8:467.

Sačkov, I., Hlásny, T., Bucha, T., Juriš, M., 2017b: Integration of tree allometry rules to treetops detection and tree crowns delineation using airborne lidar data. iForest, 10:459-467.

Sačkov, I., Kulla, L., Bucha, T., 2019: A Comparison of Two Tree Detection Methods for Estimation of Forest Stand and Ecological Variables from Airborne LiDAR Data in Central European Forests. Remote Sensing, 11:1431.

Singh, P. S., Chutia, D., Sudhakar, S., 2017: Development of a web based GIS application for spatial natural resources information system using effective open source software and standards. Journal of Geographic Information System, 4:261-266.
Stratil, M., Renner, O., 2019: Virtual forest. In: Proceedings of GIS Ostrava 2019-Smart City, Smart Region, Ostrava, p. 1-6.

Surový, P., Kuželka, K., 2019: Acquisition of Forest Attributes for Decision Support at the Forest Enterprise Level Using Remote-Sensing Techniques - A Review. Forests, 10:273.

Vauhkonen, J., Maltamo, M., McRoberts, R.E., Næsset, E., 2014: Introduction to forestry applications of airborne laser scanning. In: Maltamo, M., Næsset, E., Vauhkonen, J. (eds.): Forestry Application of Airborne Laser Scanning: Concept and Case Studies. Springer Netherlands: Dordrecht, The Netherlands, p. 1-16.

Véga, C., Renaud, J., Durrieu, S., Bouvier, M., 2016: On the interest of penetration depth, canopy area and volume metrics to improve Lidar-based models of forest parameters. Remote Sensing of Environment, 175:32-42.

Wang, H., Chen, X., Polys, N., Sforza, P., 2017:A web3D forest geo-visualization and user interface evaluation. In: Proceedings of ACM Web3D 2017 conference, Brisbane, QLD, Australia, p. 1-9.

Zápotocký, M., Koreň, M., 2016: Webová aplikácia pre sprístupnenie digitálnych máp vysokoškolského lesníckeho podniku. Kartografické listy/Cartographic letters, 24:103-111.

Zhang, Z., Cao, L., She, G., 2017: Estimating forest structural parameters using canopy metrics derived from airborne LiDAR data in subtropical forests. Remote Sensing, 9:940. 